Article

\title{
Acid Hydrolysis of Lignocellulosic Biomass: Sugars and Furfurals Formation
}

\author{
Katarzyna Świątek ${ }^{1, *}$, Stephanie Gaag ${ }^{2}$, Andreas Klier ${ }^{2}$, Andrea Kruse ${ }^{1} \oplus$, Jörg Sauer ${ }^{2} \oplus$ and \\ David Steinbach ${ }^{2}$ (1) \\ 1 Department of Conversion Technologies of Biobased Resources, Institute of Agricultural Engineering, \\ University of Hohenheim, Garbenstrasse 9, 70599 Stuttgart, Germany; andrea_kruse@uni-hohenheim.de \\ 2 Karlsruhe Institute of Technology (KIT), Institute for Catalysis Research and Technology, \\ Hermann-von-Helmholtz-Platz, 76344 Eggenstein-Leopoldshafen, Germany; \\ gaag.stephanie@gmail.com (S.G.); andreas.klier@me.com (A.K.); j.sauer@kit.edu (J.S.); \\ david.steinbach@partner.kit.edu (D.S.) \\ * Correspondence: katarzyna.swiatek@uni-hohenheim.de; Tel.: +49-711-459-24737
}

Received: 17 March 2020; Accepted: 12 April 2020; Published: 17 April 2020

\begin{abstract}
Hydrolysis of lignocellulosic biomass is a crucial step for the production of sugars and biobased platform chemicals. Pretreatment experiments in a semi-continuous plant with diluted sulphuric acid as catalyst were carried out to measure the time-dependent formation of sugars (glucose, xylose, mannose), furfurals, and organic acids (acetic, formic, and levulinic acid) at different hydrolysis temperatures $\left(180,200,220^{\circ} \mathrm{C}\right)$ of one representative of each basic type of lignocellulose: hardwood, softwood, and grass. The addition of the acid catalyst is followed by a sharp increase in the sugar concentration. Xylose and mannose were mainly formed in the initial stages of the process, while glucose was released slowly. Increasing the reaction temperature had a positive effect on the formation of furfurals and organic acids, especially on hydroxymehtylfurfural (HMF) and levulinic acid, regardless of biomass type. In addition, large amounts of formic acid were released during the hydrolysis of miscanthus grass. Structural changes in the solid residue show a complete hydrolysis of hemicellulose at $180^{\circ} \mathrm{C}$ and of cellulose at $200{ }^{\circ} \mathrm{C}$ after around 120 min reaction time. The results obtained in this study can be used for the optimisation of the hydrolysis conditions and reactor design to maximise the yields of desired products, which might be sugars or furfurals.
\end{abstract}

Keywords: spruce wood; beech wood; miscanthus; pretreatment; hydroxymethylfurfural; HMF; furfural; hydrolysate; glucose; xylose

\section{Introduction}

Renewable lignocellulosic feedstocks have potential for large-scale production of biofuels and chemicals in second generation biorefineries with sugars from cellulose and hemicellulose as intermediates [1]. Lignocellulosic biomass is composed mainly of cellulose, hemicellulose, and lignin, as well as some minor compounds like inorganics and extractives [2,3]. The fractionation at rather mild conditions is applied to get sugars to feed microorganism. Fermentable sugars are mainly used for bioethanol production, where the most important intermediate is glucose. Here, mild reaction conditions are employed to minimise the formation of fermentation inhibitors. This sugar can also be used for platform chemical production, for example, hydroxymethylfurfural (HMF) [4], by chemical pathways. Modification of the existing hydrolysis process would directly provide platform chemicals like HMF, furfural, and levulinic acid as primary products [5]. In this case, more severe reaction conditions can be applied, because the fact that these compounds may inhibit yeasts is of no importance. Additional research is needed to establish the conditions required for their efficient production $[6,7]$. 
The composition of lignocellulosic biomass varies in softwood, hardwood, and grasses. One representative of each group is investigated in this study, including spruce wood, beech wood, and Miscanthus $x$ giganteus. Miscanthus is an interesting candidate for a key energy crop, because it grows rapidly and produces an annual crop without the need for replanting with very low input requirements. Reported miscanthus harvestable yield in Europe is in the range of 5 to $44 \mathrm{tha}^{-1}$ (dry matter). However, that yield depends on the genotype, location, and harvest time [8]. It is characterised by a high energy content and low moisture content after harvest; therefore, miscanthus is expected to play an essential role in the sustainable production of chemicals in biorefineries via thermochemical conversion $[9,10]$.

Both beech and spruce trees are some of the major forest trees in Europe and are available year-round. A representative of European softwood species is spruce wood. It produces high-quality timber, very important for the pulp and paper industry [11]. These biomasses differ from each other in the proportions of cellulose, hemicellulose, and lignin, as well as in the particular composition of the hemicellulose and lignin [12,13]. The typical composition of carbohydrate fraction is presented in Table 1. As can be seen, the dominant sugar in beech wood hemicellulose (hardwood) and miscanthus (grass) is xylose, while spruce wood (softwood) contained more mannose than other biomasses.

Table 1. Comparison of the cell composition of beech and spruce wood, and Miscanthus x giganteus.

\begin{tabular}{cccc}
\hline & Beech Wood $^{\mathbf{1}}$ & Spruce Wood $^{\mathbf{2}}$ & ${\text { Miscanthus } \text { x giganteus }^{3}}^{\mathbf{3}}$ \\
\hline Cellulose & 36.30 & $(\mathrm{wt} \%)$ \\
Hemicellulose & 34.74 & 23.00 & 38.20 \\
Arabinose & 0.72 & 1.48 & 24.30 \\
Xylose & 25.80 & 5.98 & 1.80 \\
Galactose & 1.05 & 2.46 & 19.00 \\
Glucose & 1.91 & 3.06 & 0.40 \\
Mannose & 1.60 & 8.62 & 0.27 \\
Rhamnose & 0.63 & 0.26 & 0.10 \\
\hline
\end{tabular}

The key for maximising the value of lignocellulosic biomass, owing to its structural recalcitrance, is the efficient and cost-effective transformation of these three polymeric constituents, that is, cellulose, hemicellulose, and lignin. So, the central unit operation in a lignocellulosic biorefinery is biomass fractionation whereby, for example, soluble sugars and other valuable products streams are obtained $[5,18]$. Various pretreatment methods have different effects on the biomass structure. In some methods, cellulose might be removed from the biomass structure, which is particularly observed in hydrothermal and acidic pretreatment methods. Meanwhile, the second type of method consists of removing of lignin, especially at alkaline conditions [5]. One of the most cost-effective methods for the recovery of sugars from lignocellulosic biomass is acid-catalysed hydrothermal fractionation. Often, sulphuric acid is used for this purpose. It is a relatively inexpensive and strong acid, and thus makes cost-intensive acid recovery unnecessary. An alternative is hydrochloric acid, which is also a low cost, strong acid and can be recovered by distillation. However, hydrochloric acid is highly corrosive, which increases the costs for the construction materials of equipment $[19,20]$.

Hemicellulose and cellulose are broken down via hydrolysis during dilute acid pretreatment and soluble sugars are obtained. In general, the hydrolysis of hemicellulose produces sugars (glucose, xylose, mannose, and galactose) and organic acids (formic, acetic acid). Xylose is a pentose sugar, which may further be dehydrated to furfural [21,22]. In contrast to hemicellulose, cellulose has higher stability, owing to a high degree of polymerisation, its crystallinity, and the presence of hydrogen bonds. This prevents the onset of cellulose hydrolysis in milder conditions [23]. Under acidic conditions, cellulose can be hydrolysed to glucose, and then glucose can be subsequently transformed to value-added chemicals such as HMF [24-27]. During acid-catalysed pretreatment, only low amounts 
of lignin are removed in forms of soluble fragments. Lignin is a complex aromatic polymer with a very random structure. It is mainly composed of phenylpropanoid units. A lot of research is currently underway to obtain valuable chemicals, for example, phenols, from lignin [28-30].

Lignocellulosic hydrolysis using dilute acid solutions has been intensively studied and is reviewed by Steinbach et al. [5] and Kang et al. [31]. Furthermore, hydrothermal treatment of beech wood was presented in the work of Nitsos et al. [32], spruce wood by Kačíková et al. [33], and Miscanthus $x$ giganteus by Zhou et al. [34]. Most experimental studies were performed in batch systems $[19,35,36]$, where intermediate compounds like sugars underwent considerable consecutive reactions. Using a semi-continuous reaction setup, the formation of intermediates can be examined in more detail, and so more insights into the hydrolysis process can be obtained [37]. Conversion of biomass in a semi-continuous reaction setup was performed with woody biomass [38] and rye straw [39]. Further, studies in a continuous reactor on the hydrolysis of seaweed and corn stover were performed by Park et al. [40] and Schell et al. [41], respectively. The results obtained strongly depend on the feedstock and operational conditions employed, like reaction time or temperature.

The selection of optimum pretreatment conditions for lignocellulose is crucial for maximising the yields of sugars and/or furfurals in the product fluid. Furthermore, for the industrial implementation of a process, not only the maximisation of the yields, but also the minimisation of the production costs is essential. So, an optimum has to be determined between high yields at elevated reaction conditions and, on the other side, simple processes at a short reaction time, which leads to small equipment size and investment.

Pretreatment experiments with diluted sulphuric acid were carried out for a better understanding of lignocellulosic biomass fractionation. In this study, three different feedstocks, beech wood chips, spruce wood chips, and Miscanthus $x$ giganteus, were used. The experiments were performed in a semi-continuous mini plant, where water-soluble compounds, such as sugar monomers or furfurals, were quickly removed from the hot reaction zone, and thus protected as far as possible from secondary reactions. By the continuous removal of the liquid phase, the time dependence of formation of soluble organic compounds (sugars, furfurals, and organic acids) was determined. For each biomass, the influence of hydrolysis temperature on the formation of these compounds was investigated. Additionally, the yields of the main components like sugars, furfurals, and organic acids are determined for different treatment durations. In order to fully determine the effect of pretreatment conditions on the resulting products, structural changes in the solid residue were also examined.

\section{Results}

\subsection{Influence of Temperature on Beech Wood Hydrolysis}

Beech wood chips were pretreated in the presence of $0.05 \mathrm{~mol} \mathrm{~L}^{-1}$ sulphuric acid. A volume flow of $15 \mathrm{~mL} \mathrm{~min}^{-1}$ of the acid was kept constant during the experiment. The reaction temperature was varied in the fixed bed reactor and was $180^{\circ} \mathrm{C}, 200^{\circ} \mathrm{C}$, or $220^{\circ} \mathrm{C}$. Time curves of the formation of the main hydrolysis products are shown in Figures 1 and 2 . The negative values of time represent the preheating period with a flow of demineralised water. The time $t=0$ min corresponds to switching from demineralised water to acid solution in the feed stream.

During the preheating time with demineralised water to $180{ }^{\circ} \mathrm{C}$, mainly xylose was detected; see Figure 1A. The production of xylose grows rapidly, after changing from water to the acid solution. At the same point, the formation of glucose and mannose was observed. The formation of xylose reached a maximum between 10 and 15 minutes' duration. A longer reaction duration caused a substantial decrease in the concentration. The production of glucose largely increased after $10 \mathrm{~min}$ and remained at a steady level until the end of the measurement. The concentration of mannose was almost constant during hydrolysis and an order of magnitude lower than the concentration of other measured sugars. 


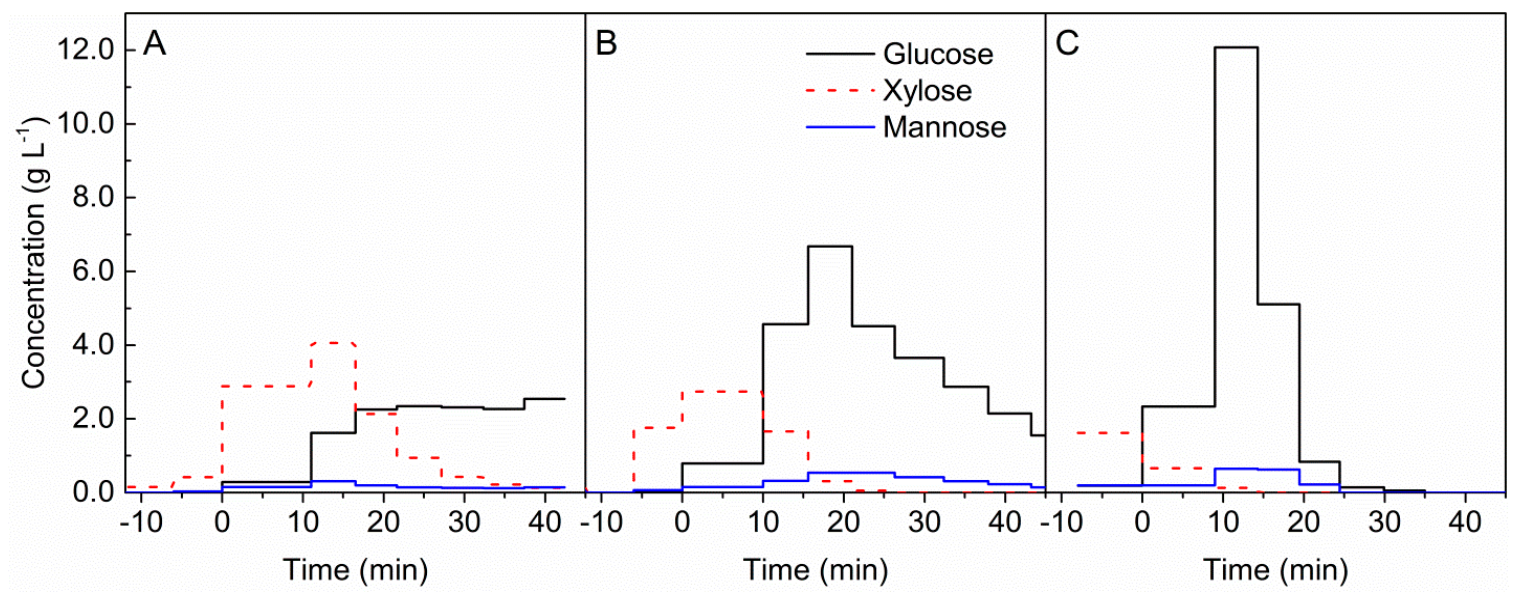

Figure 1. Formation of sugars during the hydrolysis of beech wood with $0.05 \mathrm{~mol} \mathrm{~L}^{-1}$ sulphuric acid at different temperatures of $(\mathrm{A}) 180^{\circ} \mathrm{C},(\mathrm{B}) 200^{\circ} \mathrm{C}$, and (C) $220^{\circ} \mathrm{C} . t=0 \mathrm{~min}$ marks the beginning of acid hydrolysis.

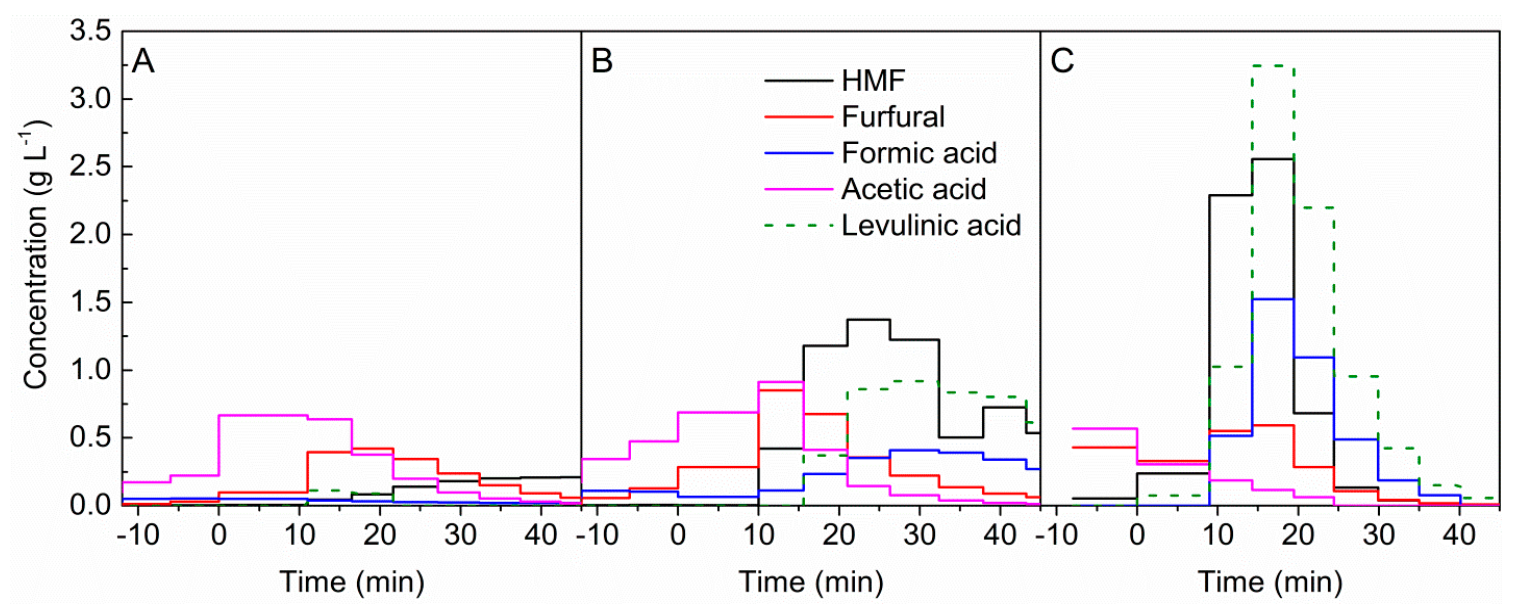

Figure 2. Formation of furfurals and organic acids during the hydrolysis of beech wood with $0.05 \mathrm{~mol} \mathrm{~L}^{-1}$ sulphuric acid at temperatures of $(\mathbf{A}) 180^{\circ} \mathrm{C},(\mathbf{B}) 200{ }^{\circ} \mathrm{C}$, and (C) $220^{\circ} \mathrm{C} . t=0$ min marks the beginning of acid hydrolysis. HMF, hydroxymehtylfurfural.

At a reaction temperature of $200{ }^{\circ} \mathrm{C}$, formation of glucose increased after addition of the acid catalyst; see Figure 1B. The highest concentration of this sugar was achieved with an experiment duration of around $20 \mathrm{~min}$. After this time, a decrease in glucose concentration was observed. Formation of xylose already started at $200{ }^{\circ} \mathrm{C}$ under hydrothermal conditions during preheating. The almost complete disappearance of xylose was achieved after $20 \mathrm{~min}$. No rapid changes in mannose concentration were noticed, which is the same as in the case at $180^{\circ} \mathrm{C}$.

At a reaction temperature of $220^{\circ} \mathrm{C}$, glucose formation had the highest concentration $\left(12 \mathrm{~g} \mathrm{~L}^{-1}\right)$ after $10 \mathrm{~min}$; see Figure 1C. After $30 \mathrm{~min}$ reaction duration, glucose concentrations were very low. The concentrations of xylose were already decreasing at $220^{\circ} \mathrm{C}$ during the hydrothermal heating. Mannose was mainly formed between 10 and 20 min reaction time in low concentrations.

After about $10 \mathrm{~min}$ of acid hydrolysis at $180^{\circ} \mathrm{C}$, an abrupt increase in furfural concentration was observed; see Figure 2A. After reaching the maximum, furfural concentration decreased with a longer reaction duration. Another measured furanic compound was HMF. Its concentration gradually increased up to $40 \mathrm{~min}$ of hydrolysis, and then the formation of this compound stayed on an equal level. Formation of formic, acetic, and levulinic acid started under preheating conditions. The addition of the acid catalyst resulted in a substantial increase in acetic acid formation. Formic acid was produced in the same order of magnitude over the entire sampling period. 
As shown in Figure 2B, the maximum of the furfural concentration at $200^{\circ} \mathrm{C}$ was observed earlier than the maximum HMF concentration. In contrast to hydrolysis at $180^{\circ} \mathrm{C}, \mathrm{HMF}$ reached higher concentrations than furfural. At a higher temperature, the formation of organic acids was higher compared with at $180^{\circ} \mathrm{C}$. During the hydrolysis, acetic acid was formed up to $20 \mathrm{~min}$, and then a rapid decrease was observed. In comparison with a lower temperature, the concentrations of acetic acid at $200{ }^{\circ} \mathrm{C}$ were similar. The maxima of the formic acid and levulinic acid concentrations were both in the range of 20 to $40 \mathrm{~min}$ of the biomass reaction duration.

At $220^{\circ} \mathrm{C}$, furfural was formed under hydrothermal conditions, and the addition of acid catalyst did not increase its formation; see Figure 2C. After $30 \mathrm{~min}$, furfural was detected in low concentrations. The concentrations of HMF, as well as levulinic and formic acid, undergo distinct maxima, which are between 15 and 20 min reaction time. In contrast to hydrolysis at lower temperatures, the formation of acetic acid was decreased already during the hydrothermal heating.

The temperature influence on lignocellulose hydrolysis was also determined using softwood (spruce) and grass (miscanthus) biomass. The data for spruce and miscanthus are shown in the Supplementary Materials, Figures S2-S5. Additionally, as a reference, hydrolysis of beech wood without acid catalyst addition was performed. The biomass was hydrolysed under hydrothermal conditions at $220^{\circ} \mathrm{C}$ with demineralised water. The data are presented in the Supplementary Materials, Figure S6.

\subsection{Influence of Biomass Type on Hydrolysis Products Formation}

The pretreatment was carried out under the same conditions for each biomass. The results with hydrolysis temperature of $200{ }^{\circ} \mathrm{C}$ are described here, whereas data for temperatures of $180{ }^{\circ} \mathrm{C}$ and $220^{\circ} \mathrm{C}$ are shown in the Supplementary Materials, Figures S2-S5. Miscanthus $x$ giganteus, beech, and spruce wood chips were pretreated in the presence of $0.05 \mathrm{~mol} \mathrm{~L}^{-1}$ sulphuric acid. A volume flow of $15 \mathrm{~mL} \mathrm{~min}^{-1}$ of the acid was kept constant during the experiment.

As shown in Figure 3 for each of the biomasses, the dominant sugar was glucose. Formation of glucose at $200^{\circ} \mathrm{C}$ increased after switching water to the acid solution. The highest concentration of this sugar was achieved after $10 \mathrm{~min}$ of the experiment for every biomass. However, for beech wood (see Figure 3A), this concentration was two times higher than for spruce wood (see Figure 3B) and miscanthus (see Figure 3C). After reaching the maximum, a decrease in glucose production was observed for both kinds of wood. Glucose formation for miscanthus was stable up to $90 \mathrm{~min}$.

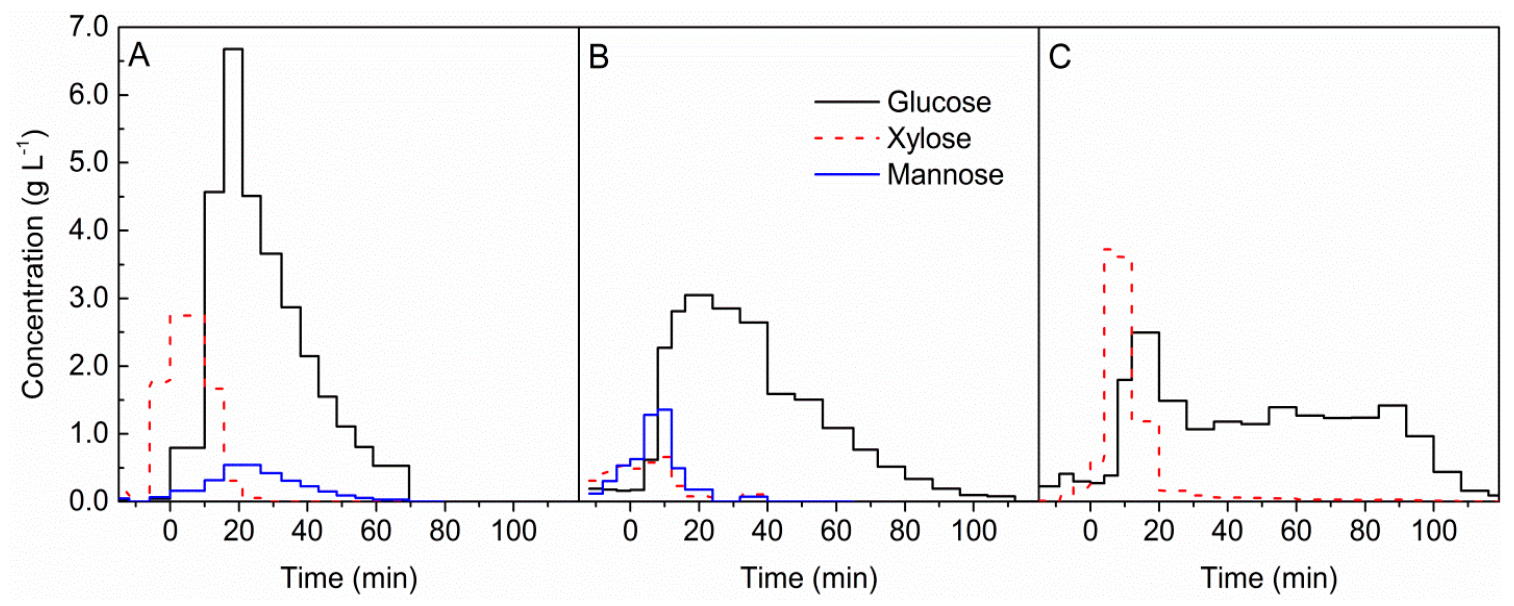

Figure 3. Formation of sugars during the hydrolysis of (A) beech wood, (B) spruce wood, and (C) Miscanthus $x$ giganteus with $0.05 \mathrm{~mol} \mathrm{~L}^{-1}$ sulphuric acid at a temperature of $200{ }^{\circ} \mathrm{C}$. $t=0$ min marks the beginning of acid hydrolysis. 
For beech wood and miscanthus, a relatively high concentration of xylose was observed. Formation of xylose already started at $200{ }^{\circ} \mathrm{C}$ under hydrothermal conditions. For woods, almost complete disappearance of xylose was observed after $20 \mathrm{~min}$, and for miscanthus, xylose was formed in a small amount over the entire duration of hydrolysis. At a lower temperature, xylose was the dominant sugar in beech wood and miscanthus hydrolysates, which is shown in Figure 1 and the Supplementary Materials, Figure S4.

Mannose was formed only during hydrolysis of beech and spruce woods. However, at $180^{\circ} \mathrm{C}$, for spruce wood, mannose was the sugar with the highest concentration right after glucose; see Supplementary Materials, Figure S2. Mannose was formed mainly at the initial stage of hydrolysis for spruce wood and, after $20 \mathrm{~min}$, a decrease in the concentration was observed. For beech wood, the highest mannose concentration was reached at around $20 \mathrm{~min}$, but it was formed over the entire duration of the hydrolysis process.

HMF was the product with the highest concentration obtained from the degradation of sugars for beech and spruce woods, as shown in Figure 4A,B. An increase in HMF concentration occurred with the addition of the acid catalyst. After reaching the maximum, the concentration of HMF decreased faster for beech wood compared with spruce wood and miscanthus; see Figure 4C. For the latter, HMF was formed for a longer duration of the hydrolysis process. Another measured furanic compound was furfural. The maximum of the furfural concentration for each biomass was observed earlier than the maximum HMF concentration. In contrast to HMF, furfural was mainly formed up to 40 min of the process.

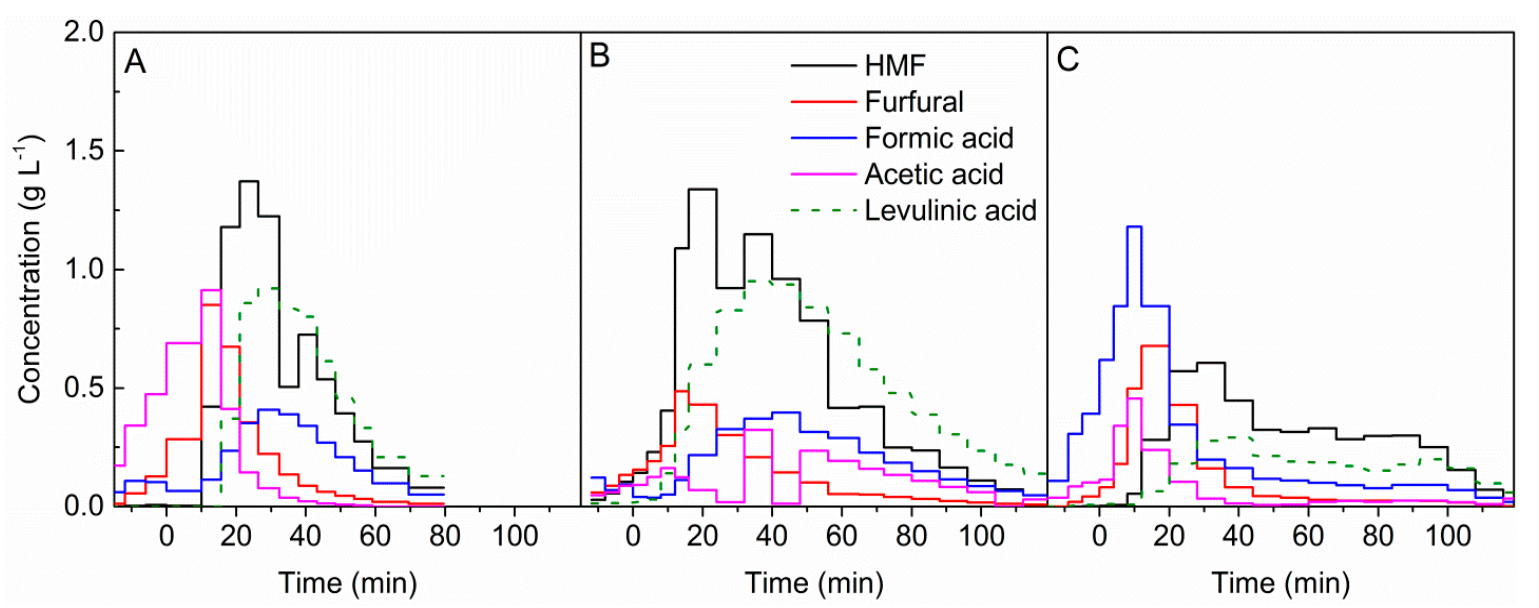

Figure 4. Formation of furfurals and organic acids during the hydrolysis of (A) beech wood, (B) spruce wood, and (C) Miscanthus $x$ giganteus with $0.05 \mathrm{~mol} \mathrm{~L}^{-1}$ sulphuric acid at a temperature of $200{ }^{\circ} \mathrm{C}$. $t=0$ min marks the beginning of acid hydrolysis.

For both woody biomasses at $200^{\circ} \mathrm{C}$, the dominant organic acid was levulinic acid. As shown in Figure 4, the formation of levulinic acid was similar to the formation of HMF for each biomass. The maximum of the levulinic acid concentration was in the range of 20 to 40 min reaction duration for beech and spruce wood. While for miscanthus formation at a constant level, similar formation to that of HMF was observed. In the same time range, the maximum concentration of formic acid was achieved for both kinds of wood. For this acid, the formation curve course was also identical that of to levulinic acid. In contrast to woody biomass, formic acid was the dominant organic acid in miscanthus hydrolysates, regardless of the temperature, as can be seen in the Supplementary Materials, Figure S5. Formation of this acid was the highest under hydrothermal preheating. For miscanthus, the maximum acetic acid concentration was obtained in the first minutes of the hydrolysis, and then only small amounts were formed. While for spruce wood, erratic concentrations were observed. 
Total Products Yield

The yield of sugars, furfurals, and organic acids from the temporal concentration curves was calculated for reaction durations of 20,40, and $60 \mathrm{~min}$ with acid catalyst. So, the formation of components during heat-up with water is not considered in this yield calculation. To show the yield changes depending on reaction duration and temperatures, data for spruce wood were chosen; see Table 2. The results for the three different biomasses are presented for a hydrolysis temperature of $200{ }^{\circ} \mathrm{C}$ and $40 \mathrm{~min}$ in Table 3, whereas data for other temperatures and reaction durations are shown in the Supplementary Materials, Tables S1 and S2.

Table 2. Main components yield after spruce wood hydrolysis with $0.05 \mathrm{~mol} \mathrm{~L}^{-1}$ sulphuric acid at different temperatures. HMF, hydroxymehtylfurfural.

\begin{tabular}{|c|c|c|c|c|c|c|c|c|c|}
\hline \multicolumn{10}{|c|}{ Yield (mg g ${ }^{-1}$ Dry Biomass) } \\
\hline & & $180^{\circ} \mathrm{C}$ & & & $200{ }^{\circ} \mathrm{C}$ & & & $220^{\circ} \mathrm{C}$ & \\
\hline $\mathrm{t}(\min )$ & 20 & 40 & 60 & 20 & 40 & 60 & 20 & 40 & 60 \\
\hline Glucose & 26.5 & 61.4 & 92.4 & 36.73 & 94.58 & 124.54 & 53.0 & 63.5 & 63.5 \\
\hline Xylose & 17.6 & 25.7 & 26.5 & 8.31 & 9.49 & 9.49 & 5.1 & 5.8 & 5.8 \\
\hline Mannose & 29.6 & 44.5 & 47.7 & 16.24 & 17.55 & 17.55 & 6.1 & 6.6 & 6.6 \\
\hline HMF & 3.0 & 11.0 & 17.7 & 13.20 & 35.78 & 51.88 & 35.5 & 46.2 & 46.7 \\
\hline Furfural & 2.8 & 7.9 & 10.6 & 6.26 & 12.23 & 14.48 & 9.6 & 14.2 & 14.9 \\
\hline Formic acid & 1.0 & 2.4 & 3.6 & 1.89 & 8.53 & 15.58 & 12.3 & 27.9 & 30.6 \\
\hline Acetic acid & 3.1 & 5.4 & 5.8 & 2.36 & 5.47 & 8.30 & 2.0 & 2.3 & 2.3 \\
\hline Levulinic acid & 0.9 & 3.9 & 7.3 & 4.60 & 21.74 & 39.40 & 28.4 & 64.3 & 71.2 \\
\hline
\end{tabular}

Table 3. Main components yield after 40 min hydrolysis of different biomass with $0.05 \mathrm{~mol} \mathrm{~L}^{-1}$ sulphuric acid at $200^{\circ} \mathrm{C}$.

\begin{tabular}{cccc}
\hline \multicolumn{4}{c}{ Yield $\mathbf{~ m g ~ g ~}^{\mathbf{- 1}}$ Dry Biomass) } \\
\hline & Beech wood & Spruce wood & Miscanthus \\
\hline $\mathrm{t}$ (min) & 40 & 40 & 40 \\
Glucose & 148.0 & 94.6 & 70.7 \\
Xylose & 42.0 & 9.5 & 60.8 \\
Mannose & 15.1 & 17.6 & 0.0 \\
HMF & 30.2 & 35.8 & 19.8 \\
Furfural & 16.8 & 12.2 & 18.5 \\
Formic acid & 10.6 & 8.5 & 29.7 \\
Acetic acid & 17.1 & 5.5 & 9.0 \\
Levulinic acid & 20.1 & 21.7 & 8.2 \\
\hline
\end{tabular}

For glucose, an extension of the reaction duration from 20 to 40 min resulted in a more than twofold increase in yield for both 180 and $200{ }^{\circ} \mathrm{C}$; see Table 2 . Meanwhile, further extension of the reaction time to $60 \mathrm{~min}$ caused a smaller increase. Only for miscanthus did a longer reaction duration have a big effect on glucose yield. This is because, for this biomass, glucose was released over the entire duration of hydrolysis. Regardless of biomass type and temperature, the xylose yields nearly stayed constant from 20 to $60 \mathrm{~min}$. The reason is that xylose was formed mainly at the initial stage of hydrolysis. The highest xylose yields were reported for miscanthus. While for spruce wood, the yield of xylose was nearly seven times lower. Changes in mannose yield were only observed for beech wood, where an extension of the reaction duration from 20 to $40 \mathrm{~min}$ resulted in a twofold yield increase. This means that, similar to xylose, mannose was formed mainly at the initial stage of the process and during the heat-up phase. Therefore, a decrease in the yield of these two sugars was observed when process temperature increased because, for this yield calculation, only the acid-catalysed reaction duration was considered, excluding the heat-up phase. 
In general, a longer reaction time and higher temperature for each biomass had a positive effect on HMF yield. This was especially visible for miscanthus. At $200^{\circ} \mathrm{C}$, an extension of the reaction duration from 20 to $40 \mathrm{~min}$ resulted in an eightfold higher yield. At the considered reaction time, the highest HMF yield was for spruce wood, then for beech wood, and then miscanthus. The furfural yield did not show major changes depending on the biomass type. A reaction time extension to 40 min resulted in up to a twofold furfural yield increase compared with $20 \mathrm{~min}$ hydrolysis time at 200 and $220^{\circ} \mathrm{C}$.

The highest formic acid yields were obtained for miscanthus, while a longer reaction duration resulted in a 50\% yield increase. Acetic acid yield changes were most pronounced for spruce wood. However, this acid did not show high yield changes along with temperature. Extension of the reaction duration from 20 to $40 \mathrm{~min}$ doubled the yield of this organic acid. The next extension of the reaction time from 40 to $60 \mathrm{~min}$ increased the yield by $50 \%$. However, comparing yield values, the highest acetic acid yields were obtained for beech wood, followed by miscanthus. Among the discussed organic acids, reaction duration and temperature had the highest impact on levulinic acid yield. This acid yield at $200{ }^{\circ} \mathrm{C}$ after $60 \mathrm{~min}$ for miscanthus was even 25 times higher than that after $20 \mathrm{~min}$. For beech and spruce wood, this yield was 16 and 13 times higher, respectively.

\subsection{Influence of Hydrolysis Temperature on Solid Residue}

It was observed that a higher temperature of hydrolysis caused the residue to become darker and more brittle when touched. The structural changes in the solid residue after pretreatment of beech wood were investigated using thermogravimetric analysis and infrared spectroscopy.

The changes in the thermogram of solid residues after sulphuric acid hydrolysis compared with starting biomass are shown in Figure 5. The DTG curve of untreated beech wood shows a small peak at $80{ }^{\circ} \mathrm{C}$, which is owing to residual moisture. It follows a large peak at $360^{\circ} \mathrm{C}$ with an upstream peak shoulder at about $300^{\circ} \mathrm{C}$. At a hydrolysis temperature of $180^{\circ} \mathrm{C}$, the peak shoulder initially disappears at $300{ }^{\circ} \mathrm{C}$, whereas the peak at $360^{\circ} \mathrm{C}$ shifts slightly forward. A sharply changed thermogram was obtained at a hydrolysis temperature of $200{ }^{\circ} \mathrm{C}$, because the peak at $360^{\circ} \mathrm{C}$ nearly disappeared. Besides, a new peak can be observed at around $415^{\circ} \mathrm{C}$. A further increase in temperature to $220^{\circ} \mathrm{C}$ resulted in complete disappearance of the peak at $360^{\circ} \mathrm{C}$.

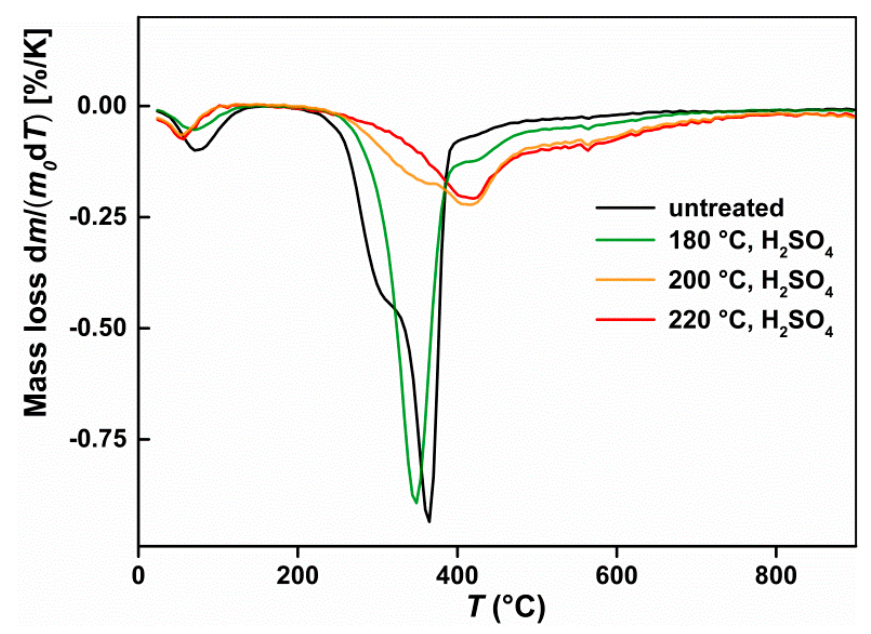

Figure 5. Thermogram (DTG curves) of untreated beech wood and the solid residue after hydrolysis with $0.05 \mathrm{~mol} \mathrm{~L}^{-1}$ sulphuric acid at different temperatures.

FT-IR spectra of beech wood and solid residues from the sulphuric acid hydrolysis are shown in Figure 6. Changes in the FT-IR spectra from starting biomass to the solid residues are observed. Moreover, among the solid residues, there are differences in the IR absorption depending on the pretreatment conditions. In all solid residues, the beech wood bands disappear at 1740 and $1245 \mathrm{~cm}^{-1}$. After pretreatment with sulphuric acid at higher temperatures, the bands at 1370, 1160, and $1035 \mathrm{~cm}^{-1}$ 
become smaller. Ultimately, new bands appear after pretreatment at 1710 and $1210 \mathrm{~cm}^{-1}$ for a hydrolysis temperature of $200^{\circ} \mathrm{C}$.

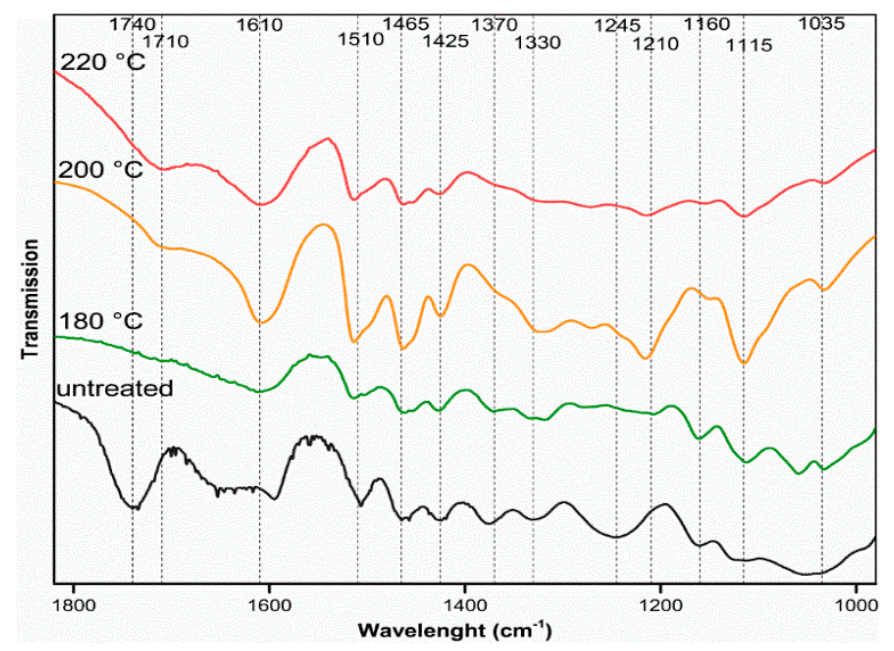

Figure 6. FT-IR spectra of untreated beech wood and solid residue after pretreatment with $0.05 \mathrm{~mol} \mathrm{~L}^{-1}$ sulphuric acid at different temperatures; adsorption range from $1800 \mathrm{~cm}^{-1}$ to $1000 \mathrm{~cm}^{-1}$.

\section{Discussion}

\subsection{Dissolved Products Formation}

In a semi-continuous process, small and soluble compounds are washed out of the reactor and measured. Here, the structure of biomass is of special importance. The cellulose fibres are stabilized by crystallinity and interconnected with hydrogen bonds. The hydrogen bonds are so strong that no swelling can occur in subcritical water. Therefore, hydrolysis occurs only at the "outer edges" of the crystalline parts or at amorphous parts [42]. Therefore, the hydrolysis of cellulose, especially with high crystallinity, is slower than that of hemicellulose. As in other publications of semi-continuous and acid-catalysed hydrolysis of biomass, the formation of oligomers is not considered, because it is known that the amount and life-time is low [43].

Glucose could originate from either the hemicellulose or cellulose fractions of lignocellulose. The glucose liberated at mild hydrolysis conditions most likely originated from hemicellulose, while the main part of glucose originated from the cellulose fraction $[44,45]$. The cellulose required a longer time to react at $200{ }^{\circ} \mathrm{C}$ compared with at $220^{\circ} \mathrm{C}$, owing to its stable and organised structure [46].

The cellulose in beech wood was hydrolysed slowly to glucose at $180{ }^{\circ} \mathrm{C}$ with $0.05 \mathrm{~mol} \mathrm{~L}^{-1}$ sulphuric acid, as indicated by the long release time of the glucose; see Figure 1 . For spruce wood and miscanthus at $200{ }^{\circ} \mathrm{C}$, glucose formation was completed after $120 \mathrm{~min}$; see Figure 3. This indicates that cellulose was completely reacted. For beech wood, glucose formation decreased after $70 \mathrm{~min}$; see Figure 3.

Hemicellulose is easily hydrolysed in water at temperatures above $180{ }^{\circ} \mathrm{C}$ [47]. This is because of a lack of repeating glycosidic bonds, and thus the random nature of the hemicellulose polymer [46]. This is probably why hydrolysates from beech, spruce wood, and miscanthus contained glucose, even at heat-up with water; see Figure 1, Figures S2 and S4. This is because all these lignocelluloses contain glucose in the hemicellulose structure, as shown in Table 1. This is in accordance with work concerning the hydrothermal treatment of hardwood and softwood [48]. Glucose released at a later stage of the process does not originate from hemicellulose. Otherwise, glucose and xylose would be hydrolysed simultaneously. Meanwhile, xylose shows an early maximum.

The hemicellulosic framework in the biomasses did not hydrolyse completely under hydrothermal preheating to $180{ }^{\circ} \mathrm{C}$. This is visible as the release of xylose and mannose (for woods) increased 
rapidly after addition of the acid catalyst; see Figure 1, Figures S2 and S4. However, when heated to $180^{\circ} \mathrm{C}$, a part of the acetylated side chains was already hydrolysed, which was visible by acetic acid release, especially for beech wood. Nevertheless, by hydrothermal heating to $220^{\circ} \mathrm{C}$, the hemicellulose was largely hydrolysed, which is noticeable by declining concentrations of xylose and acetic acid during heat-up. As xylose was released during the hydrothermal heating phase to $220^{\circ} \mathrm{C}$ and glucose production began in the acid catalyst environment, it is possible to separate xylose-rich and glucose-rich hydrolysates. This is of special interest when different downstream conversions for these sugars are intended.

Low concentrations of mannose in hydrolysates could be caused by the fact that hardwood contains a small amount of glucomannan in its structure [49]. However, for beech wood, mannose was released later than xylose, especially at hydrolysis temperatures of $200{ }^{\circ} \mathrm{C}$ and $220^{\circ} \mathrm{C}$; see Figure 1 . Therefore, it could be assumed that the released mannose does not originate from the hemicellulose because, otherwise, mannose and xylose would be released at the same time. Mannose was released mainly when the glucose concentration was high. So, taking into account the discussed course of mannose formation, it could be assumed that glucose might epimerize to mannose.

It has to be considered that the parameter "time" here is the reaction duration for the solid material. Glucose, for example, is solved and transported out of the reactor to depress secondary reactions to furfurals, among others. This is important when the results are compared to batch experiments, wherein the reaction time for all species is the same [50]. This may explain why the differences in hydrothermal batch experiments without acids are lower [48] —here, the consecutive reaction is more slowly, but can occur, owing to the long reactions times.

HMF is formed from hexoses in acid-catalysed processes. Here, therefore, the HMF formation is observed at a shorter duration/lower temperature compared with similar experiments without acid addition [39]. Formic and levulinic acid are consecutive products formed simultaneously in equimolar yield when HMF rehydrates [51]. The yield of HMF and its degradation products gradually raised when the hydrolysis temperature was increased, regardless of the type of biomass; see Table 2 and Tables S1 and S2. However, formic acid was also released during heating to $180^{\circ} \mathrm{C}$ and $200^{\circ} \mathrm{C}$ under hydrothermal conditions, probably coming from the elimination of formyl groups originally linked to hemicellulose xylan [52]. This was especially noticeable for miscanthus, where the formic acid formation was similar to xylose formation, even at $220^{\circ} \mathrm{C}$. However, the formation of formic acid may also occur in different pathways, that is, sugars defragmentation, via (1) furfuryl alcohol, (2) furfural formation (3) pyruvaldehyde, and (4) D-erythrose [53].

During the pretreatment, furfural is generated by the dehydration of liberated xylose. As can be seen in Table 2 and Tables S1 and S2, only a small change in furfural yield is obtained, despite the changing xylose yields along with the temperature and type of biomass. This is because not all of the xylose consumed will end up as furfural. The reason being that two consecutive reactions of furfural-furfural resinification and furfural condensation—can take place [52].

Acetic acid is formed from hydrolysis of the acetyl groups in the hemicellulose, as a consequence of deacetylation of acetylated pentosane [54]. Furthermore, acetic acid can also originate from the defragmentation of sugars $[55,56]$. This is why the formation of acetic acid is dependent not only on the biomass type, but on the hydrolysis temperature too.

For the application of the hydrolysis process for a biorefinery, the yields are of special importance. When pretreatment with $0.05 \mathrm{~mol} \mathrm{~L}^{-1}$ sulphuric acid was performed, the yield of glucose was maximised at $200{ }^{\circ} \mathrm{C}$ for all feedstocks. The highest glucose yield was obtained for beech wood, $148 \mathrm{mg} \mathrm{g}^{-1}$, while for miscanthus, the yield was twofold lower. At lower temperatures, the hydrolysis of the cellulose has not progressed so far. At $220^{\circ} \mathrm{C}$, a more substantial part of the glucose undergoes subsequent reactions. This can also be seen from the sharp increase in the yields of levulinic acid and formic acid, which are consecutive products of glucose; see Table 2, Tables S1 and S2.

The yield of xylose decreased in the considered time intervals of acid-catalysed hydrolysis with higher temperatures because the hemicellulose is already hydrolysed during the heat-up of 
the lignocellulose under hydrothermal conditions. Xylose yields were the highest for beech wood, $42 \mathrm{mg} \mathrm{g}^{-1}$, and miscanthus, $61 \mathrm{mg} \mathrm{g}^{-1}$, because they have higher xylose content in the hemicellulose structure. The same yield decrease applied to acetic acid. For beech wood, the generally larger acetic acid yields can be explained by the high degree of acetylation of xylans in hardwood [57].

For spruce wood, the decrease in mannose yields at a higher temperature can also be explained by the hydrolysis of the hemicellulose in the heating phase. In beech wood, which contains a lower amount of mannose in the hemicellulose, this argumentation is not sufficient to describe the course of the yields.

The yield of HMF increased with the hydrolysis temperature for all the biomasses, although the increase from $200{ }^{\circ} \mathrm{C}$ to $220^{\circ} \mathrm{C}$ was much weaker than from $180^{\circ} \mathrm{C}$ to $200{ }^{\circ} \mathrm{C}$; see Table 2 and Tables S1 and S2. This is partly because of the strongly increasing rehydration of HMF to levulinic acid and formic acid at $220^{\circ} \mathrm{C}$. Consequently, a further increase in the reaction temperature would, above all, increase the yields of these two organic acids at the expense of HMF. Optimization of the hydrolysis reaction conditions for maximising HMF yields is thus not desirable, as this would also increase the yields of the HMF derivatives. Comparing biomasses, the highest HMF yield was achieved from woods, while for miscanthus, the yield was about $40 \%$ lower.

On the basis of the obtained results, it can be concluded that all three biomasses-beech, spruce wood, and miscanthus-have great potential for bio-based platform chemical production. It should be emphasized that miscanthus can compete with woody biomass. Considering the other advantages of this feedstock as well, it deserves wider interest.

\subsection{Solid Residue Changes}

After pretreatment with sulphuric acid at $180{ }^{\circ} \mathrm{C}$, the peak shoulder at $300{ }^{\circ} \mathrm{C}$, which can be assigned to the hemicellulose [58], firstly disappears in the thermogram; Figure 5. This indicates a complete breakdown of hemicellulose. This is also the reason the solid residue appears to be brittle. Further, in other studies, for example, Chen et al. [59], the peak shoulder of hemicellulose disappeared after pretreatment at $180^{\circ} \mathrm{C}$, or even $160^{\circ} \mathrm{C}$. By contrast, the pretreatment temperature of $180^{\circ} \mathrm{C}$ does not appear to have an effect on the cellulose, as the cellulose peak at $360^{\circ} \mathrm{C}$ remains mostly unchanged.

At a hydrolysis temperature of $200^{\circ} \mathrm{C}$, the cellulose has already mainly been converted, which can be confirmed by the disappearance of the cellulose peak at $360{ }^{\circ} \mathrm{C}$ [60]. There appears to be a temperature threshold above which the crystalline regions of cellulose either undergo structural change and/or are degraded by hydrolysis [61]. This temperature threshold is in the pretreatment of beech with $0.05 \mathrm{~mol} \mathrm{~L}-1$ sulphuric acid between $180{ }^{\circ} \mathrm{C}$ and $200{ }^{\circ} \mathrm{C}$. The process is not well understood yet. The temperature still is too low to enable a transformation of crystalline cellulose to amorphous, but may change the structure of lignin [62]. This may influence the hydrolysis behaviour, as the lignin may cover the cellulose.

After pretreatment with sulphuric acid, a new, broad peak at approximately $415{ }^{\circ} \mathrm{C}$ is generated in the thermogram. The peak is still weak at a pretreatment temperature of $180^{\circ} \mathrm{C}$, but becomes more abundant at a pretreatment temperature of $200{ }^{\circ} \mathrm{C}$. The emergence of a new peak in the region of $410-420^{\circ} \mathrm{C}$ was also observed in the sulphuric acid-catalysed pretreatment of miscanthus, as well as in the hydrothermal carbonisation of various lignocelluloses [63-65]. It can be assumed that the $415^{\circ} \mathrm{C}$ peak is an inert pseudo lignin formed by solid-to-solid transformations of the polysaccharides [66].

IR spectroscopy in Figure 4 shows that, after pretreatment of beech wood, the $\mathrm{C}=\mathrm{O}$ valence vibration at $1740 \mathrm{~cm}^{-1}$ has disappeared, which can be attributed to the acetylated side chains of the hemicellulose [67]. Thus, the acetylated side chains of hemicellulose are fully hydrolysed at all pretreatment conditions tested. This is related to the work of Xiao et al. [67], which investigated hydrothermal pretreatment at lower temperatures of $100-200^{\circ} \mathrm{C}$. They found that the $\mathrm{C}=\mathrm{O}$ valence vibration at $1740 \mathrm{~cm}^{-1}$ decreases with the increasing hydrolysis temperature. Further, the skeleton of the hemicellulose is completely hydrolysed, which can be visualized with the disappearance of the $\mathrm{C}-\mathrm{O}$ stretching vibration at $1245 \mathrm{~cm}^{-1}$ [68]. Moreover, in the studies of Chen et al. [59] and 
Sannigrahi et al. [69] after pretreatment, the $\mathrm{C}-\mathrm{O}$ valence vibration of hemicellulose disappeared at $1245 \mathrm{~cm}^{-1}$.

The hydrolysis of the cellulose was mostly completed when the sulphuric acid hydrolysis was carried out at $200^{\circ} \mathrm{C}$. Only then did the $\mathrm{C}-\mathrm{O}$ stretching vibration of the cellulose disappear completely at $1370 \mathrm{~cm}^{-1}$. This is consistent with the decrease in $\mathrm{C}-\mathrm{O}-\mathrm{C}$ valence vibration of glycosidic bonds at $1160 \mathrm{~cm}^{-1}$ [68].

The newly occurring $\mathrm{C}=\mathrm{O}$ stretching vibration at $1710 \mathrm{~cm}^{-1}$ after sulphuric acid pretreatment can be attributed to pseudo lignin structures. This newly formed band was also found after the pretreatment of lignin-removed poplar [69]. The newly formed band at $1210 \mathrm{~cm}^{-1} \mathrm{can}$ also be derived from pseudo lignin.

The enhancement of the aromatic $C=C$ valence vibration at 1610 and $1510 \mathrm{~cm}^{-1}$ was also reported by Chen et al. and Xiao et al. and can be justified by two hypotheses [59,67]. First, condensation reactions of reactive intermediates can form new aromatics. On the other hand, the relative proportion of the aromatic structures in the solid residue increases because lignin is enriched by the hydrolysis of the polysaccharides. The latter also explains why the $\mathrm{C}-\mathrm{H}$ valence vibration of methoxy groups at $2840 \mathrm{~cm}^{-1}$ becomes visible at higher temperatures.

\section{Materials and Methods}

\subsection{Feedstocks}

In this study, three different lignocellulosic feedstocks were used in chip size. Wood chips from pre-dried and bark-free beech wood were obtained from Joh. Sinnerbrink GmbH \& Co (Verl, Germany). The chips had a length of about $30 \mathrm{~mm}$, a width of about $15 \mathrm{~mm}$, and a thickness of 1-2 mm, and were used without further drying. Spruce wood chips came from the Hermann Keller GmbH sawmill (Achern, Germany) with a length of about $35 \mathrm{~mm}$, a width of $6-20 \mathrm{~mm}$, and a thickness of about $4 \mathrm{~mm}$. Originally spruce wood chips contained $48 \mathrm{wt} \%$ of water and were gently air-dried at $40{ }^{\circ} \mathrm{C}$ for six days.

Miscanthus $x$ giganteus was cultivated at the fields of the University of Hohenheim (Stuttgart, Germany), and harvested in the fall of 2017 with subsequent sun-drying on the field. Then, samples were chopped with a cutting mill with a $4 \mathrm{~mm}$ sieve diameter. The results of the proximate and ultimate analysis of the feedstocks are shown in Table 4. Elemental analysis of the feedstocks was performed on a CHNS analyser EuroEA, 3000 Series (HEKAtech GmbH, Wegberg, Germany) according to the standard (DIN-51732). The moisture and ash content were analysed according to industrial standard proximate analysis (ASTM D1762-84). The measurements were made in duplicates, and the average data were reported.

Table 4. Proximate and ultimate analysis of the feedstocks.

\begin{tabular}{ccccccc}
\hline \multicolumn{1}{c}{ Biomass } & \multicolumn{7}{c}{ Parameter (wt\%) } \\
\hline & $\mathrm{C}^{1}$ & $\mathrm{H}^{1}$ & $\mathrm{~N}^{1}$ & $\mathrm{~S}^{1}$ & Ash $^{1}$ & Moisture $^{2}$ \\
\hline Beech wood & 50.2 & 6.0 & 0.2 & 0.2 & 0.5 & 8.0 \\
Spruce wood & 48.3 & 6.6 & 0.1 & 0.1 & 0.3 & 3.0 \\
Miscanthus x giganteus & 53.7 & 6.7 & 0.5 & - & 3.2 & 12.0 \\
\hline
\end{tabular}

${ }^{1}$ based on dry material, ${ }^{2}$ based on pre-dried material.

\subsection{Diluted Acid Hydrothermal Fractionation}

The pretreatment experiments of the lignocellulosic biomass with dilute sulphuric acid were performed using a semi-continuous mini plant. A process flow diagram of the plant is shown in the Supplementary Materials, Figure S1. A self-constructed 1.4571-stainless steel reactor with an internal volume of $100 \mathrm{~mL}$ was used. The reactor was clamped during the experiment in metallic heating 
blocks. For temperature measurement, two thermocouples with accuracy $\pm 1^{\circ} \mathrm{C}$ were placed in the reactor-one at the bottom and one at the middle. The reactor (R-1-SM, Figure S1) was loaded before the experiment with pre-dried biomass in chips size as a fixed bed. The biomass mass was $15.0 \mathrm{~g}$ of spruce and beech wood and $12.0 \mathrm{~g}$ of miscanthus. From a feed tank, the demineralised water (T-1) or dilute acid solution (T-2) was continuously pumped with a flow of $15 \mathrm{~mL} \mathrm{~min}^{-1}$ into the reactor by a preparative high-performance liquid chromatography (HPLC) pump (P-1). The liquid stream was not pre-heated before entering the reactor. The average residence time of the liquid in the reactor was $7 \mathrm{~min}$, which was determined by a residence time distribution experiment using the step response method. During the heating phase (ca. $40 \mathrm{~min}$ ), demineralised water was pumped through the reactor (R-1). When the required temperature in the reactor was reached, the feed stream was switched to acid solution. The liquid left the reactor continuously and was cooled in a heat exchanger (HE-1), and then collected in interval samples of 5-8 min duration. The samples were stored at $4{ }^{\circ} \mathrm{C}$. After the experiment, demineralised water was pumped through the reactor for about $60 \mathrm{~min}$ to cool down the solid residue. Then, this residue was manually removed from the reactor. The total residence time of solid residue in the reactor was about 240 min including heat-up and cool down.

Sulphuric acid was selected as the hydrolysis catalyst with a concentration of $0.05 \mathrm{~mol} \mathrm{~L}^{-1}$, corresponding to a $0.49 \mathrm{wt} \%$ solution. This is a typical concentration range that is used in industrial pretreatment units [70]. The hydrolysis process was carried out at a pressure of 25 bar and at three temperatures of 180,200 , and $220^{\circ} \mathrm{C}$.

\subsection{Analytical Methods}

\subsubsection{Analysis of Liquid Products}

Characterisation of the liquid samples was performed with different high-performance liquid chromatography (HPLC) systems. Preliminary filtration with $0.45 \mu \mathrm{m}$ GHP syringe filters (Pall, New York, NY, USA) was performed to remove solid particles.

The first HPLC system for analysing monosaccharides (glucose, xylose, and mannose) consisted of an amperometric detector with a gold working electrode in pulsed measuring mode. Chromatographic separation was achieved using a Metrosep Carb 2 column (Metrohm, Filderstadt, Germany), which was maintained at $35^{\circ} \mathrm{C}$ by the heater. The mixture of $0.1 \mathrm{~mol} \mathrm{~L}^{-1}$ sodium hydroxide aqueous solution and $0.01 \mathrm{~mol} \mathrm{~L}^{-1}$ sodium acetate as an eluent passed through the column at a flow rate of $0.5 \mathrm{~mL} \mathrm{~min}{ }^{-1}$. The accuracy of peak identification and sugar concentration was crossed checked with another HPLC method using MetaCarb $87 \mathrm{C}$ colum from Agilent (Santa Clara, CA, USA) at $85{ }^{\circ} \mathrm{C}$ with $0.6 \mathrm{~mL} \mathrm{~min}{ }^{-1}$ of water eluent and RI-detector. The crossed check result confirmed the qualification correctness.

The second HPLC system for determination of HMF and furfural was equipped with a UV detector at a wavelength of $290 \mathrm{~nm}$. Isocratic elution was performed with 9:1 (volume ratio) water-acetonitrile mobile phase with a flow rate of $1.4 \mathrm{~mL} \mathrm{~min}^{-1}$ and a LiChrospher $100 \mathrm{RP}-18$ column (Merck, Darmstadt, Germany) at a column temperature of $20^{\circ} \mathrm{C}$.

Short-chain organic acids were quantified by a third HPLC system. The eluent used is a $0.004 \mathrm{~mol} \mathrm{~L}^{-1}$ sulphuric acid solution at a flow rate of $0.65 \mathrm{~mL} \mathrm{~min}^{-1}$. The separation in the column is carried out either at $60^{\circ} \mathrm{C}$, for levulinic acid determination, or at $25^{\circ} \mathrm{C}$, for formic and acetic acid. The Aminex HPX - 87H (Biorad, Hercules, CA, USA) separation column was used. Detection takes place with two detectors connected in series-RI and DAD.

The yield of the sugars, furfurals, and organic acids from the temporal concentration curves was calculated according to Equation (1).

$$
Y=\frac{1}{m_{\text {input }}} \int_{0}^{t_{1}} \dot{V i n} \text {. } c(t) d t
$$


where $Y\left(\mathrm{mg} \cdot \mathrm{g}_{\text {biomass }}^{-1}\right), m_{\text {input }}(\mathrm{g}), t_{1}(\mathrm{~min}), \dot{\mathrm{V}}\left(\mathrm{L} \mathrm{min}^{-1}\right)$, and $c(t)\left(\mathrm{mg} \mathrm{L}^{-1}\right)$ correspond to the component yield, dry mass of the used feedstock, reaction duration, diluted sulphuric acid solution flow, and sample interval concentration of a component, respectively. For comparison of yields of the main components, moderate reaction durations (relative to the lignocellulosic biomass residue) of 20,40, and $60 \mathrm{~min}$ were selected.

\subsubsection{Analysis of Solid Residue}

The analysis of the solids after pretreatment of beech wood was carried out by thermal and spectroscopic measurement methods. Before the analysis, solid residues from the hydrolysis were dried at $105^{\circ} \mathrm{C}$ for $16 \mathrm{~h}$.

Thermogravimetric analysis (TGA) was carried out on a thermobalance TGA851 from Mettler-Toledo (Columbus, OH, USA) at a heating rate of $10 \mathrm{~K} \mathrm{~min}^{-1}$ to $900{ }^{\circ} \mathrm{C}$ under a nitrogen atmosphere. Around $10 \mathrm{mg}$ of the dried and ground sample was weighed.

The IR-spectra were recorded with an FT-IR spectrometer 660-IR from Varian (Palo Alto, CA, USA) in transmittance mode for wavenumbers of $4000-400 \mathrm{~cm}^{-1}$. The IR spectroscopy of the dried and ground samples was carried out using $\mathrm{KBr}$ pellets and the obtained spectra were normalized.

\section{Conclusions}

Hydrolysis of lignocellulosic materials is a crucial step for sugars as well as biobased platform chemicals production (HMF, furfural, levulinic acid). A semi-continuous reactor type was used because it allows to combine rather a long reaction time for the low-reactive components of biomass and a short reaction time for the reactive hydrolysis products.

This study focused on dilute acid hydrolysis at different temperatures of three lignocellulosic feedstocks. At the same reaction conditions, cellulose in beech wood required nearly a twofold shorter time to react than for spruce wood and miscanthus. A temperature increase from $200{ }^{\circ} \mathrm{C}$ to $220^{\circ} \mathrm{C}$ led to a considerable faster hydrolysis reaction and, at the same time, the yields of the obtained sugars were reduced. A concomitant shortening of the reaction time of the solid would generally have a positive effect on the profitability of a possible process because high product concentrations facilitate the purification and, at the same time, less wastewater is obtained. As consequence of the faster hydrolysis of hemicellulose compared with cellulose, most of the difference between the three feedstocks reflects the different composition and content of the hemicellulose. The hydrolysates from beech wood and miscanthus contained more xylose than spruce wood hydrolysates. Furthermore, the release of glucose already started at hydrothermal conditions.

At higher temperatures, sugar derivative products such as organic acids increase, which causes reduced glucose yields. From the time course of the main components in the pretreatment of lignocellulose, it can be concluded that HMF, levulinic acid, and formic acid are secondary products of hexoses, whereas furfural is a secondary product of xylose. However, the formic and acetic acid formation also depends on the biomass type.

Structural changes in the solid residue show that a complete hydrolysis was obtained after around $120 \mathrm{~min}$ reaction time (1) at $180{ }^{\circ} \mathrm{C}$ in the case of hemicellulose and (2) at $200^{\circ} \mathrm{C}$ in the case of cellulose. At higher pretreatment temperatures, larger amounts of an inert pseudo lignin are formed.

The results obtained in this study show that both temperature and time have a strong impact on the formation of hydrolysis products. The optimization of the hydrolysis conditions to maximise the desired products of both sugars and furfurals is crucial for the efficient use of biomass.

Supplementary Materials: The following are available online at http://www.mdpi.com/2073-4344/10/4/437/s1, Figure S1: Process flow diagram of the mini plant for the fractionation of biomass; Figure S2: Formation of sugars in the hydrolysis of spruce wood; Figure S3: Formation of furfurals and organic acids in the hydrolysis of spruce wood; Figure S4: Formation of sugars in the hydrolysis of miscanthus; Figure S5: Formation of furfurals and organic acids in the hydrolysis of miscanthus; Figure S6: Formation of sugars and furfurals in the hydrolysis of beech wood without acid catalyst. Table S1: Main components yield after beech wood hydrolysis; Table S2: Main components yield after miscanthus hydrolysis. 
Author Contributions: Conceptualization, K.Ś. and D.S.; investigation, K.Ś., S.G., A.K. (Andreas Klier) and D.S.; writing—original draft preparation, K.Ś.; writing—review and editing, D.S., A.K. (Andrea Kruse) and J.S.; visualization, K.S. ; supervision, A.K. (Andrea Kruse) and J.S. All authors have read and agreed to the published version of the manuscript.

Funding: This research was funded by the GRACE project, which has received funding from the Bio-Based Industries Joint Undertaking under the European Union's Horizon 2020 research and innovation programme under grant agreement No 745012. This work of Katarzyna Światek was supported by the Ministry of Science, Research, and Arts of Baden-Württemberg within the framework of the Bioeconomy Research Program Baden-Württemberg (project: Lignocellulose biorefinery for the Bioeconomy in Baden-Württemberg (B4B)). Additionally, this work was financially supported by the German Federal Ministry of Food, Agriculture, and Consumer Protection (FNR project number 22027811) based on a decision of the German Bundestag.

Acknowledgments: We acknowledge Nicolaus Dahmen for project supervision. Matthias Pagel and Thomas Tietz built the pretreatment reactor. Chromatographic analytics were supported by Sonja Habicht, Armin Lautenbach, Birgit Rolli, and Veronika Holderied.

Conflicts of Interest: The authors declare no conflict of interest.

\section{References}

1. Luque, R.; Herrero-Davila, L.; Campelo, J.M.; Clark, J.H.; Hidalgo, J.M.; Luna, D.; Marinas, J.M.; Romero, A.A. Biofuels: A technological perspective. Energy Environ. Sci. 2008, 1, 542. [CrossRef]

2. Huijgen, W.J.J.; Smit, A.T.; de Wild, P.J.; den Uil, H. Fractionation of wheat straw by prehydrolysis, organosolv delignification and enzymatic hydrolysis for production of sugars and lignin. Bioresour. Technol. 2012, 114, 389-398. [CrossRef] [PubMed]

3. Dahmen, N.; Lewandowski, I.; Zibek, S.; Weidtmann, A. Integrated lignocellulosic value chains in a growing bioeconomy: Status quo and perspectives. GCB Bioenergy 2019, 11, 107-117. [CrossRef]

4. Chatterjee, C.; Pong, F.; Sen, A. Chemical conversion pathways for carbohydrates. Green Chem. 2015, 17, 40-71. [CrossRef]

5. Steinbach, D.; Kruse, A.; Sauer, J. Pretreatment technologies of lignocellulosic biomass in water in view of furfural and 5-hydroxymethylfurfural production- A review. Biomass Conv. Bioref. 2017, 7, 247-274. [CrossRef]

6. Raman, J.K.; Gnansounou, E. LCA of bioethanol and furfural production from vetiver. Bioresour. Technol. 2015, 185, 202-210. [CrossRef]

7. Zhang, K.; Agrawal, M.; Harper, J.; Chen, R.; Koros, W.J. Removal of the Fermentation Inhibitor, Furfural, Using Activated Carbon in Cellulosic-Ethanol Production. Ind. Eng. Chem. Res. 2011, 50, 14055-14060. [CrossRef]

8. Brosse, N.; Dufour, A.; Meng, X.; Sun, Q.; Ragauskas, A. Miscanthus: A fast-growing crop for biofuels and chemicals production. Biofuels Bioprod. Bioref. 2012, 6, 580-598. [CrossRef]

9. Lewandowski, I.; Clifton-Brown, J.C.; Scurlock, J.M.O.; Huisman, W. Miscanthus: European experience with a novel energy crop. Biomass Bioenergy 2000, 19, 209-227. [CrossRef]

10. Lewandowski, I.; Clifton-Brown, J.; Kiesel, A.; Hastings, A.; Iqbal, Y. Miscanthus. In Perennial Grasses for Bioenergy and Bioproducts; Elsevier: Amsterdam, The Netherlands, 2018; pp. 35-59. ISBN 9780128129005.

11. Larsson, T.-B. European Forest Types, Categories and Types for Sustainable Forest Management Reporting and Policy; Technical Report No 9/2006; European Environment Agency: Copenhagen, Denmark, 2007.

12. Lygin, A.V.; Upton, J.; Dohleman, F.G.; Juvik, J.; Zabotina, O.A.; Widholm, J.M.; Lozovaya, V.V. Composition of cell wall phenolics and polysaccharides of the potential bioenergy crop -Miscanthus. GCB Bioenergy 2011, 3, 333-345. [CrossRef]

13. Demirbaş, A. Estimating of Structural Composition of Wood and Non-Wood Biomass Samples. Energy Sources 2005, 27, 761-767. [CrossRef]

14. Willför, S.; Sundberg, A.; Pranovich, A.; Holmbom, B. Polysaccharides in some industrially important hardwood species. Wood Sci. Technol. 2005, 39, 601-617. [CrossRef]

15. Willför, S.; Sundberg, A.; Hemming, J.; Holmbom, B. Polysaccharides in some industrially important softwood species. Wood Sci. Technol. 2005, 39, 245-257. [CrossRef]

16. De Vrije, T.; de Haas, G.G.; Tan, G.B.; Keijsers, E.R.P.; Claassen, P.A.M. Pretreatment of Miscanthus for hydrogen production by Thermotoga elfii. Int. J. Hydrog. Energy 2002, 27, 1381-1390. [CrossRef] 
17. Schäfer, J.; Sattler, M.; Iqbal, Y.; Lewandowski, I.; Bunzel, M. Characterization of Miscanthus cell wall polymers. GCB Bioenergy 2019, 11, 191-205. [CrossRef]

18. FitzPatrick, M.; Champagne, P.; Cunningham, M.F.; Whitney, R.A. A biorefinery processing perspective: treatment of lignocellulosic materials for the production of value-added products. Bioresour. Technol. 2010, 101, 8915-8922. [CrossRef]

19. Lenihan, P.; Orozco, A.; O'Neill, E.; Ahmad, M.N.M.; Rooney, D.W.; Walker, G.M. Dilute acid hydrolysis of lignocellulosic biomass. Chem. Eng. J. 2010, 156, 395-403. [CrossRef]

20. Chen, W.-H.; Tu, Y.-J.; Sheen, H.-K. Impact of dilute acid pretreatment on the structure of bagasse for bioethanol production. Int. J. Energy Res. 2010, 34, 265-274. [CrossRef]

21. Lange, J.-P. Lignocellulose conversion: an introduction to chemistry, process and economics. Biofuels Bioprod. Bioref. 2007, 1, 39-48. [CrossRef]

22. Schwiderski, M.; Kruse, A.; Grandl, R.; Dockendorf, D. Comparison of the influence of a Lewis acid $\mathrm{AlCl} 3$ and a Brønsted acid $\mathrm{HCl}$ on the organosolv pulping of beech wood. Green Chem. 2014, 16, 1569-1578. [CrossRef]

23. Jönsson, L.J.; Martín, C. Pretreatment of lignocellulose: Formation of inhibitory by-products and strategies for minimizing their effects. Bioresour. Technol. 2016, 199, 103-112. [CrossRef] [PubMed]

24. Dautzenberg, G.; Gerhardt, M.; Kamm, B. Bio based fuels and fuel additives from lignocellulose feedstock via the production of levulinic acid and furfural. Holzforschung 2011, 65, A69. [CrossRef]

25. Chheda, J.N.; Román-Leshkov, Y.; Dumesic, J.A. Production of 5-hydroxymethylfurfural and furfural by dehydration of biomass-derived mono- and poly-saccharides. Green Chem. 2007, 9, 342-350. [CrossRef]

26. Yu, I.K.M.; Tsang, D.C.W. Conversion of biomass to hydroxymethylfurfural: A review of catalytic systems and underlying mechanisms. Bioresour. Technol. 2017, 238, 716-732. [CrossRef]

27. Körner, P.; Jung, D.; Kruse, A. The effect of different Brønsted acids on the hydrothermal conversion of fructose to HMF. Green Chem. 2018, 20, 2231-2241. [CrossRef]

28. Wang, H.; Pu, Y.; Ragauskas, A.; Yang, B. From lignin to valuable products-strategies, challenges, and prospects. Bioresour. Technol. 2019, 271, 449-461. [CrossRef]

29. Fu, D.; Farag, S.; Chaouki, J.; Jessop, P.G. Extraction of phenols from lignin microwave-pyrolysis oil using a switchable hydrophilicity solvent. Bioresour. Technol. 2014, 154, 101-108. [CrossRef]

30. Forchheim, D.; Hornung, U.; Kruse, A.; Sutter, T. Kinetic Modelling of Hydrothermal Lignin Depolymerisation. Waste Biomass Valorization 2014, 5, 985-994. [CrossRef]

31. Kang, S.; Fu, J.; Zhang, G. From lignocellulosic biomass to levulinic acid: A review on acid-catalyzed hydrolysis. Renew. Sustain. Energy Rev. 2018, 94, 340-362. [CrossRef]

32. Nitsos, C.K.; Matis, K.A.; Triantafyllidis, K.S. Optimization of Hydrothermal Pretreatment of Lignocellulosic Biomass in the Bioethanol Production Process. ChemSusChem 2013, 6, 110-122. [CrossRef]

33. Kačíková, D.; Kačík, F.; Čabalová, I.; Ďurkovič, J. Effects of thermal treatment on chemical, mechanical and colour traits in Norway spruce wood. Bioresour. Technol. 2013, 144, 669-674. [CrossRef] [PubMed]

34. Zhou, X.; Li, Q.; Zhang, Y.; Gu, Y. Effect of hydrothermal pretreatment on Miscanthus anaerobic digestion. Bioresour. Technol. 2017, 224, 721-726. [CrossRef] [PubMed]

35. Karimi, K.; Kheradmandinia, S.; Taherzadeh, M.J. Conversion of rice straw to sugars by dilute-acid hydrolysis. Biomass Bioenergy 2006, 30, 247-253. [CrossRef]

36. Larsson, S.; Palmqvist, E.; Hahn-Hägerdal, B.; Tengborg, C.; Stenberg, K.; Zacchi, G.; Nilvebrant, N.-O. The generation of fermentation inhibitors during dilute acid hydrolysis of softwood. Enzym. Microb. Technol. 1999, 24, 151-159. [CrossRef]

37. Yu, Y.; Wu, H. Understanding the Primary Liquid Products of Cellulose Hydrolysis in Hot-Compressed Water at Various Reaction Temperatures. Energy Fuels 2010, 24, 1963-1971. [CrossRef]

38. Matsunaga, M.; Matsui, H.; Otsuka, Y.; Yamamoto, S. Chemical conversion of wood by treatment in a semi-batch reactor with subcritical water. J. Supercrit. Fluids 2008, 44, 364-369. [CrossRef]

39. Ingram, T.; Rogalinski, T.; Bockemühl, V.; Antranikian, G.; Brunner, G. Semi-continuous liquid hot water pretreatment of rye straw. J. Supercrit. Fluids 2009, 48, 238-246. [CrossRef]

40. Park, J.-H.; Hong, J.-Y.; Jang, H.C.; Oh, S.G.; Kim, S.-H.; Yoon, J.-J.; Kim, Y.J. Use of Gelidium amansii as a promising resource for bioethanol: A practical approach for continuous dilute-acid hydrolysis and fermentation. Bioresour. Technol. 2012, 108, 83-88. [CrossRef]

41. Schell, D.J.; Farmer, J.; Newman, M.; McMillan, J.D. Dilute-sulfuric acid pretreatment of corn stover in pilot-scale reactor. Appl. Biochem. Biotechnol. 2003, 105, 69-85. [CrossRef] 
42. Tolonen, L.K.; Zuckerstätter, G.; Penttilä, P.A.; Milacher, W.; Habicht, W.; Serimaa, R.; Kruse, A.; Sixta, H. Structural changes in microcrystalline cellulose in subcritical water treatment. Biomacromolecules 2011, 12, 2544-2551. [CrossRef]

43. Mosier, N.; Wyman, C.; Dale, B.; Elander, R.; Lee, Y.Y.; Holtzapple, M.; Ladisch, M. Features of promising technologies for pretreatment of lignocellulosic biomass. Bioresour. Technol. 2005, 96, 673-686. [CrossRef] [PubMed]

44. Arslan, Y.; Takaç, S.; Eken-Saraçoğlu, N. Kinetic study of hemicellulosic sugar production from hazelnut shells. Chem. Eng. J. 2012, 185-186, 23-28. [CrossRef]

45. Fan, L.; Gharpuray, M.M.; Lee, Y.H. Cellulose Hydrolysis. Biotechnology Monographs. Acid Hydrolysis of Cellulose; Springer: Berlin/Heidelberg, Germany, 1987.

46. Peterson, A.A.; Vogel, F.; Lachance, R.P.; Fröling, M.; Michael, J.A., Jr.; Tester, J.W. Thermochemical biofuel production in hydrothermal media: A review of sub- and supercritical water technologies. Energy Environ. Sci. 2008, 1, 32-65. [CrossRef]

47. Bobleter, O. Hydrothermal degradation of polymers derived from plants. Prog. Polym. Sci. 1994, 19, 797-841. [CrossRef]

48. Nitsos, C.K.; Choli-Papadopoulou, T.; Matis, K.A.; Triantafyllidis, K.S. Optimization of Hydrothermal Pretreatment of Hardwood and Softwood Lignocellulosic Residues for Selective Hemicellulose Recovery and Improved Cellulose Enzymatic Hydrolysis. ACS Sustain. Chem. Eng. 2016, 4, 4529-4544. [CrossRef]

49. Hiltunen, S.; Sirén, H. Analysis of monosaccharides and oligosaccharides in the pulp and paper industry by use of capillary zone electrophoresis: A review. Anal. Bioanal. Chem. 2013, 405, 5773-5784. [CrossRef]

50. Ruiz, H.A.; Rodríguez-Jasso, R.M.; Fernandes, B.D.; Vicente, A.A.; Teixeira, J.A. Hydrothermal processing, as an alternative for upgrading agriculture residues and marine biomass according to the biorefinery concept: A review. Renew. Sustain. Energy Rev. 2013, 21, 35-51. [CrossRef]

51. Girisuta, B.; Janssen, L.P.B.M.; Heeres, H.J. A kinetic study on the decomposition of 5-hydroxymethylfurfural into levulinic acid. Green Chem. 2006, 8, 701. [CrossRef]

52. Zeitsch, K.J. The Chemistry and Technology of Furfural and Its Many By-Products; Elsevier: Amsterdam, The Netherlands, 2000.

53. Flannelly, T.; Lopes, M.; Kupiainen, L.; Dooley, S.; Leahy, J.J. Non-stoichiometric formation of formic and levulinic acids from the hydrolysis of biomass derived hexose carbohydrates. RSC Adv. 2016, 6, 5797-5804. [CrossRef]

54. Garrote, G.; Domínguez, H.; Parajó, J. Study on the deacetylation of hemicelluloses during the hydrothermal processing of Eucalyptus wood. Holz als Roh- und Werkst. 2001, 59, 53-59. [CrossRef]

55. Xiang, Q.; Lee, Y.Y.; Torget, R.W. Kinetics of glucose decomposition during dilute-acid hydrolysis of lignocellulosic biomass. Appl. Biochem. Biotechnol. 2004, 115, 1127-1138. [CrossRef]

56. Srokol, Z.; Bouche, A.-G.; van Estrik, A.; Strik, R.C.J.; Maschmeyer, T.; Peters, J.A. Hydrothermal upgrading of biomass to biofuel; studies on some monosaccharide model compounds. Carbohydr. Res. 2004, 339, 1717-1726. [CrossRef] [PubMed]

57. Teleman, A.; Tenkanen, M.; Jacobs, A.; Dahlman, O. Characterization of O-acetyl-(4-O-methylglucurono)xylan isolated from birch and beech. Carbohydr. Res. 2002, 337, 373-377. [CrossRef]

58. Yang, H.; Yan, R.; Chen, H.; Lee, D.H.; Zheng, C. Characteristics of hemicellulose, cellulose and lignin pyrolysis. Fuel 2007, 86, 1781-1788. [CrossRef]

59. Chen, W.-H.; Ye, S.-C.; Sheen, H.-K. Hydrolysis characteristics of sugarcane bagasse pretreated by dilute acid solution in a microwave irradiation environment. Appl. Energy 2012, 93, 237-244. [CrossRef]

60. Funke, A.; Ziegler, F. Hydrothermal carbonization of biomass: A summary and discussion of chemical mechanisms for process engineering. Biofuels Bioprod. Bioref. 2010, 4, 160-177. [CrossRef]

61. Zhang, J.; Wang, Y.; Zhang, L.; Zhang, R.; Liu, G.; Cheng, G. Understanding changes in cellulose crystalline structure of lignocellulosic biomass during ionic liquid pretreatment by XRD. Bioresour. Technol. 2014, 151, 402-405. [CrossRef]

62. Li, J.; Feng, P.; Xiu, H.; Li, J.; Yang, X.; Ma, F.; Li, X.; Zhang, X.; Kozliak, E.; Ji, Y. Morphological changes of lignin during separation of wheat straw components by the hydrothermal-ethanol method. Bioresour. Technol. 2019, 294, 122157. [CrossRef]

63. Cortés, A.M.; Bridgwater, A.V. Kinetic study of the pyrolysis of miscanthus and its acid hydrolysis residue by thermogravimetric analysis. Fuel Process. Technol. 2015, 138, 184-193. [CrossRef] 
64. Liu, F.; Guo, M. Comparison of the characteristics of hydrothermal carbons derived from holocellulose and crude biomass. J. Mater. Sci. 2015, 50, 1624-1631. [CrossRef]

65. Olszewski, M.P.; Arauzo, P.J.; Maziarka, P.A.; Ronsse, F.; Kruse, A. Pyrolysis Kinetics of Hydrochars Produced from Brewer's Spent Grains. Catalysts 2019, 9, 625. [CrossRef]

66. Kruse, A.; Zevaco, T. Properties of Hydrochar as Function of Feedstock, Reaction Conditions and Post-Treatment. Energies 2018, 11, 674. [CrossRef]

67. Xiao, L.-P.; Sun, Z.-J.; Shi, Z.-J.; Xu, F.; Sun, R.-C. Impact of hot compressed water pretreatment on the structural changes of woody biomass for bioethanol production. Bioresources 2011, 6, 1576-1598.

68. Adapa, P.K.; Schonenau, L.G.; Canam, T.; Dumonceaux, T. Quantitative analysis of lignocellulosic components of non-treated and steam exploded Barley, Canola, Oat and wheat straw using Fourier Transform Infrared Spectroscopy. J. Agric. Sci. Technol. 2011, B1, 177-188.

69. Sannigrahi, P.; Kim, D.H.; Jung, S.; Ragauskas, A. Pseudo-lignin and pretreatment chemistry. Energy Environ. Sci. 2011, 4, 1306-1310. [CrossRef]

70. Oriez, V.; Peydecastaing, J.; Pontalier, P.-Y. Lignocellulosic Biomass Fractionation by Mineral Acids and Resulting Extract Purification Processes: Conditions, Yields, and Purities. Molecules 2019, 24, 4273. [CrossRef]

(C) 2020 by the authors. Licensee MDPI, Basel, Switzerland. This article is an open access article distributed under the terms and conditions of the Creative Commons Attribution (CC BY) license (http://creativecommons.org/licenses/by/4.0/). 